\title{
Index And Engineering Properties Of Subgrade Soils: A Study In Areka Town, Wolaita Zone, Southern Ethiopia
}

\author{
Esubalew Tariku Yenialem ${ }^{1}$, Wondemagne Tadesse Borku ${ }^{2}$ \\ ${ }^{1}$ Lecturer, Department of Civil Engineering, WolaitaSodo university, WolaitaSodo, Ethiopia \\ ${ }^{1}$ Email Id: esubalewtariku@yahoo.com \\ ${ }^{2}$ Lecturer, Department of Construction Technology and Management, WolaitaSodo university, Ethiopia \\ 2 Email Id: wondetade@gmail.com \\ *Corresponding Author: Esubalew Tariku Yenialem \\ Lecturer, Department of Civil Engineering, Wolaita Sodo university, Wolaita Sodo, Ethiopia \\ Email Id: esubalewtariku@yahoo.com
}

\begin{abstract}
Civil engineering structures are designed from the knowledge of soil properties at the given site. This research work is for the Investigation of index and engineering properties of Areka town subgrade soils. To investigate these ten test pits were selected by dividing the total area of the town in to ten parts based on the expansion potential of the town and the current distribution of the gravel road according to the municipality of Areka town. The soil samples per pit up to $3 \mathrm{~m}$ depth, were collected from open pits by direct manual excavation. During field testing, field density and natural moisture content tests were done.[15] The laboratory tests that were carried out includes natural moisture content, particle size distribution, specific gravity, Atterberg limits (LL and PL), compaction (OMC and MDD), CBR and CBR swelling potential tests were conducted. From the results that were obtained for grain size analysis, Atterberg limits and from soil classification systems (USCS and AASHTO). According to the results of this research, Natural Moisture content ranged between 8.0-12.0\%, field dry density ranged between $1.66-1.87(\mathrm{~g} / \mathrm{cc})$, gravel fraction between 9.18-16.19 \%, sand fraction between 22.30-54.26\%, silt fraction between 15.82-47.69 \%, Clay fraction between 9.0-35.5\%, Specific Gravity ranges between 2.58-2.78, Plasticity Index between $8.2114 .61 \%$, GI ranges from 4 to 11 and for the soil classification under A-4, A-6, A-7-5 and A-7-6 according to AASHTO M145 and inorganic silts of medium compressibility according to unified soil classification system and the OMC ranges from $10.14 \%$ to $21.37 \%$, MDD ranges from $1.77 \mathrm{~g} / \mathrm{cc}$ to $1.98 \mathrm{~g} / \mathrm{cc}$, CBR swell ranges from $1.421 .92 \%$ and CBR value ranges from 6.31-8.76 (\%) as the test result indicate that CBR swelling potential values were below $2 \%$, therefore they were good to use as a subgrade soil for pavement construction [6]. The CBR values for the soil samples were above 5\% so they were good to use as a subgrade soil for pavement construction [11]. From all soil samples the subgrade strength class based on CBR value TP1, TP6, TP9, TP10 were S3; and the remaining were S4 [7].; thus, the subgrade soil has good bearing capacity for the pavement construction based on [4].
\end{abstract}

\section{Key words: Soil Classification, Index property of soil, engineering property of soil, subgrade soil.}

\subsection{Background of the Study}

\section{INTRODUCTION}

Every man-made structure resting on the ground needs safe and stable soil. To attain this safety and stability requirements the index and engineering properties of the soil beneath the structure or on the structure must be identified.The purpose of the subgrade is to provide a platform for construction of the pavement and to support the pavement without undue deflection that would impact the pavement's performance [ 7].

At present Ethiopia's infrastructure is expanding rapidly, as a result large number of new urban roads and lightly trafficked roads are planned or are under construction. Thus, in addition to maintenance work of existing roads and construction of the new roads results in a large amount of material testing. As Areka town is the fastest growing one, it expands in the northern and eastern parts, so there is scarcity of road.

access in this area, even the constructed road is gravel road, to construct and upgrade these roads to an asphalt pavement. 
Therefore, building a stable subgrade is a vital role for constructing an effective and long-lasting pavement system. Thus, it is very essential to characterize the sub grade by conducting visual descriptions, sampling and testing of subgrade soil along the project route were carried out to construct pavement structure.[12]

Areka is city in southern Ethiopia Located in the Wolayita Zone of the Southern Nations, Nationalities, and Peoples' Region some 300 kilometers southwest of the capital, Addis Ababa. This town has a latitude and longitude of $7^{\circ} 04^{\prime} 0.01^{\prime \prime} \mathrm{N} 37^{\circ} 42^{\prime} 0.00^{\prime \prime} \mathrm{E}$ and an elevation of 1774 meters above sea level. It is the administrative center of Boloso Sore woreda. As information collected from the Areka municipality this town subgrade soil was not done any investigation for the index and engineering properties.

\subsection{Statement of the Problem}

A civil engineering structures by far depends on the accurate estimation of index and engineering properties of the soil which are the basis for giving their intended purpose for a design period of the structures. Unless a detailed investigation is made on the index and engineering properties of the soil under consideration, geotechnical failures may encounter which are inevitable and their remedial measures are expensive and sometimes difficult.[13] Areka town is among the newly involving towns in Ethiopia, whereby needing the expansion of civil engineering structures (public and commercial buildings and residences), and infrastructures (like road, drainage structures etc.). Thus, this research is developed to determine the index and engineering properties of soils in Areka town. There is no previously done research at Areka town to classify the soil type, to determine the index and engineering properties of the soils. This work gives a better understanding about the behavior of the soil with respect to the characteristics of the subgrade soils in Areka town. It can also be used as a start point for decision makers and geotechnical designers, for the current and future expansion of civil engineering structures.[16]

\subsection{Objectives of the Study \\ The main objectives}

The main objectives of this research are determining the index and engineering properties of the subgrade soil in Areka town.

\section{The specific objective}

To describe and classify the geotechnical engineering characteristics of the subgrade soils of Areka town from commonly measured index properties based on AASHTO and USCS specifications.

$>$ To identity the engineering properties of the subgrade soil of the Areka town.

$>$ To check whether the soil of Areka town is suitable or not to use as subgrade soils.

\subsection{Sub-Grade soil}

\section{REVIEW OF LITERATURES}

Sub-Grade soil is the ultimate foundation of the road pavement structure which provides support to the pavement. The sub-grade materials and its different properties are very much important in the pavement design. The strength of the road sub grade for flexible pavements is commonly assessed in terms of the California Bearing Ratio (CBR) and this is dependent on the type of soil, its density, and its moisture content. The density of the sub grade soil can be controlled within limits by compacting at suitable moisture content at the time of construction. Its main function is to provide support to the pavement against traffic loading and should possess sufficient stability under various climate and heavy loading conditions [1].

\subsection{Engineering Characteristics of Soils}

The engineering characteristic of a soil mass depends on the proportion of these two groups of soils, and is governed by the one which dominates. [8].

The main engineering characteristics of coarse grained soils (A-1, A-2 and A-3) are:- $\square$

Generally, very good foundation material for supporting structures and roads;

- Generally, very good embankment material;

- Generally, the best backfill material for retaining walls;

- May settle under vibratory loads or blasts;

- Dewatering may be difficult in open-graded gravels due to high permeability; $\square$ Generally, not expansive.

The engineering characteristics of inorganic silts (A4 and A5)

$$
\text { are: } \quad \text { Relatively low shear strength; } \square \quad \text { Relatively low }
$$

permeability. 
The engineering characteristics of inorganic clays (A-6 and A-7) are: - $\square$

Generally, possess low shear strength;

- Plastic and compressible;

- Can lose part of shear strength upon wetting;

- Can lose part of shear strength upon disturbance;

- Generally, very poor material for backfill; $\square$ Generally poor material for embankments;

- Can be practically impervious.

The group index (GI) is a means of rating the value of a soil as a subgrade material within its own group. It is not used in order to place a soil in a particular group, that is done directly from the results of sieve analysis, the liquid limit and plasticity index. The higher the value of the group index, the poorer is the quality of the material [10].

\subsection{Index Properties of Subgrade Soil}

The physical properties of the soil which serve mainly for identification and classification purpose are commonly known as the index properties. These can be determined by laboratory tests. Index property tests are grain size analysis (both sieve analysis and hydrometer analysis), Atterberg limits (both liquid limit and plastic limit) and specific gravity determination [1].

\subsection{Engineering Properties Subgrade Soil. Moisture-Density relations}

Soils form the foundation for most highway structures. The final structure, whether it is a pavement or a bridge structure, can only be as durable as the foundation upon which it rests. Compaction of the soil is necessary in order to assure that the soil or soil aggregate structure will perform and support its intended design loads. Soil compaction is perhaps the least expensive method of improving soils [3]. Material that is densely compacted will support more load than uncompacted material.

The principles of compaction were developed by R. Proctor in the 1930's. Proctor noted that compaction is a function of four variables (Compaction Effort, Soil Type, Dry Density, and Moisture Content) [2].

\section{California Bearing Ratio (CBR),}

The California Bearing Ratio (CBR), defined as the ratio of the resistance to penetration of a material to the penetration resistance of a standard crushed stone base material. California Bearing Ratio is the main design input in pavement construction to assess the stiffness modulus and shear strength of subgrade material. The method was developed by the California Division of Highways as part of their study in pavement failure at World War II [7].The general relationship between CBR values and the quality of the subgrade soils used in pavement application is as shown in the table below.

Table 1. General Relationship between CBR Value and Quality of the Subgrade [6].

\begin{tabular}{|l|l|}
\hline $\begin{array}{l}\text { CBR } \\
(\%)\end{array}$ & Quality of the subgrade \\
\hline $0-3$ & Very poor \\
\hline $3-7$ & Poor to fair \\
\hline $7-20$ & Fair \\
\hline $20-50$ & Good \\
\hline$>50$ & Excellent \\
\hline
\end{tabular}

\subsection{The Characterization of Subgrade Soils by CBR Swell and CBR Values}

The soil material to use as a sub-grade should full fill a maximum value of $30 \%$ and $60 \%$ for PI and LL values, respectively and a minimum CBR value of $5 \%$, a swell of $2 \%$ is the maximum requirement for the standard manuals [6].

Soil unsuitable for use as a subgrade in the work may include: - peat materials and organic decomposition with more than $3 \%$ organic matter by weight, Clay materials having a liquid limit exceeding $60 \%$, or a plasticity index exceeding 30 or CBR value less than 5\% or maximum CBR swell values of 2\%. [11].

Expansive soils unsuitable subgrade soils do not meet the requirements and may need improvements to their engineering properties in order to transform these unsuitable subgrade materials into effective construction materials. This is often accomplished by physical or chemical stabilization or modification of these problematic soils [9]. 


\section{RESEARCH METHODOLOGY}

\subsection{Field Work and Sampling Methods}

Field visits to overview the geotechnical setup of the study area using GPS in order to locate the exact position of sampling and to get some inputs for the description on the geotechnical soils conditions. Visual identification of soils in the field was carried out according to ASTM D-2488

Test pits were excavated using hand tools with plan area, and representative disturbed soil samples were taken to laboratory with a great care.[16]

Table 2. Soil Sample Location of the Study Area

\begin{tabular}{|c|c|c|c|c|c|}
\hline S/No & Location & Depth (m) & Northing & Easting & $\begin{array}{l}\text { Elevation } \\
(\mathrm{m})\end{array}$ \\
\hline TP1 & Areka jouner school & 3 & $7^{0} 03^{\prime} 57^{\prime \prime}$ & $37^{\circ} 42^{\prime} 46^{\prime \prime}$ & 1736 \\
\hline TP2 & Areka Abo church & 2.5 & $7^{0} 03^{\prime} 40$, & $37^{\circ} 42^{\prime} 40^{\prime \prime}$ & 1759 \\
\hline TP3 & Areka full Gospel church & 3 & $7^{0} 03^{\prime} 47^{\prime \prime}$ & $37^{\circ} 42^{\prime} 17^{\prime \prime}$ & 1748 \\
\hline TP4 & Areka number 2 Kalehiwot church & 3 & $7^{0} 03^{\prime} 26^{\prime \prime}$ & $37^{\circ} 42^{\prime} 40^{\prime \prime}$ & 1751 \\
\hline TP5 & $\begin{array}{l}\text { Areka kingdom hall of Jehovah's } \\
\text { witnesses }\end{array}$ & 2.75 & $7^{0} 04^{\prime} 10$ & $37^{\circ} 42^{\prime} 45^{\prime \prime}$ & 1727 \\
\hline TP6 & Areka Holy Savior Catholic Church & 3 & $7^{0} 04^{\prime} 57^{\prime \prime}$ & $37^{\circ} 42^{\prime} 11^{\prime \prime}$ & 1727 \\
\hline TP7 & Areka Kalehiywot church & 2.5 & $7^{0} 04^{\prime} 41 "$ & $37^{\circ} 42^{\prime} 19^{\prime \prime}$ & 1745 \\
\hline TP8 & Areka St. Mikael church & 3 & $7^{0} 04^{\prime} 51 '$ & $37^{\circ} 42^{\prime} 25^{\prime \prime}$ & 1728 \\
\hline TP9 & Areka Mubarek Mosque & 2.75 & $7^{0} 04^{\prime} 23^{\prime \prime}$ & $37^{\circ} 42^{\prime} 20^{\prime \prime}$ & 1746 \\
\hline TP10 & Areka Apostolic church & 3 & $7^{0} 05^{\prime} 00$ & $37^{\circ} 42^{\prime} 11^{\prime \prime}$ & 1726 \\
\hline
\end{tabular}

\section{Laboratory Tests for Soil}

The laboratory tests were carried out for, natural moisture content, grain size distribution, specific gravity, Atterberg limit, moisture- density relationship, CBR swell and CBR as per ASTM standards.

Natural Moisture Content

ASTM D 2216 was followed to determine the natural moisture content of the soils. Grain

Size Analysis Test

ASTM Designation D422 was followed to carry out wet sieve, and hydrometer analysis on the soil content passing sieve No. 200 to measure the amount of silt and clay size particles in disturbed soil samples.

\section{Atterberg Limit}

ASTM designation D4318 was followed to determine the plasticity of the soils. Casagrande device was used to determine the LL of each soil passing through a $425 \mu \mathrm{m}$ sieve, was prepared for each soil. The PL of the soil was determined by using soil passing through a $425 \mu \mathrm{m}$ sieve and rolling 3-mm diameter threads of soil until it began to crack. The PI was then computed by subtracting PL form LL. Specific Gravity Test

ASTM Designation D854 was followed to determine the specific gravity of soil that is the ratio of the density of solids in the soil to the density of water.[14] Moisture - Density Relationship

ASTM D1557 was followed to determine the moisture-density relation of this research, Method A Procedure. MDD and $\mathrm{OMC}$ for the soil samples were determined by plotting the relationship between dry density and moisture content. The purpose of compaction is to improve the engineering properties of the soil, i.e. it increases the bearing capacity, and stiffness and thus, reduces future settlement, void ratio and permeability.

\section{California Bearing Ratio (CBR) and CBR swell test}

ASTM D1883 was followed to determine the CBR value of this research, The CBR test is essentially a measure of the shearing resistance of a soil at a known moisture and density conditions.

The California Bearing Ratio (CBR), defined as the ratio of the resistance to penetration of a material to the penetration resistance of a standard crushed stone base material. California Bearing Ratio is the main design input in pavement 
construction to assess the stiffness modulus and shear strength of subgrade material and the CBR swell test is the swelling potential test conducted during CBR soaking[15].

Table 3. Subgrade Strength Class [7].

\begin{tabular}{|l|l|}
\hline Subgrade Strength Class & Range, (CBR \%) \\
\hline S1 & $<3$ \\
\hline S2 & $3-4$ \\
\hline S3 & $5-7$ \\
\hline S4 & $8-14$ \\
\hline S5 & $15-29$ \\
\hline S6 & $30+$ \\
\hline
\end{tabular}

\section{RESULTS AND DISCUSSION}

The most important parameters used in this thesis study were field dry density, NMC, Gs, grain size analysis, Atterberg limit, compaction tests CBR swell and CBR value of the subgrade soils.

Table 4. Field Dry Density, Natural moisture content and Specific Gravity Test Results

\begin{tabular}{|c|c|c|c|c|}
\hline Sample No. & $\begin{array}{l}\text { Field bulk density } \\
(\mathrm{g} / \mathrm{cc})\end{array}$ & $\begin{array}{l}\text { Natural } \\
\text { moisture } \\
\text { content } \\
\%\end{array}$ & Field dry density $(\mathrm{g} / \mathrm{cc})$ & Specific Gravity \\
\hline TP1 & 1.90 & 8.0 & 1.76 & 2.70 \\
\hline
\end{tabular}

\begin{tabular}{|l|l|l|l|l|}
\hline TP2 & 2.02 & 11.0 & 1.82 & 2.60 \\
\hline TP3 & 2.00 & 9.0 & 1.83 & 2.63 \\
\hline TP4 & 2.02 & 8.0 & 1.87 & 2.75 \\
\hline TP5 & 1.89 & 9.0 & 1.73 & 2.62 \\
\hline TP6 & 1.99 & 11.0 & 1.79 & 2.60 \\
\hline TP7 & 1.82 & 9.5 & 1.66 & 2.78 \\
\hline TP8 & 2.01 & 10.0 & 1.82 & 2.58 \\
\hline TP9 & 1.90 & 12.0 & 1.70 & 2.76 \\
\hline TP10 & 1.84 & 9.0 & 1.69 & 2.66 \\
\hline
\end{tabular}


Table 5. The Grain Size Analysis Test Results for Soil Samples

\begin{tabular}{|l|l|l|l|l|l|l|}
\hline \multirow{2}{*}{ Sample No. } & \multicolumn{5}{|c|}{ Coarser grain size soil } & \multicolumn{2}{|c|}{ Finer grain size soil } \\
\cline { 2 - 7 } & $\begin{array}{l}\text { Gravel } \\
\%\end{array}$ & $\begin{array}{l}\text { Coarse } \\
\text { Sand \% }\end{array}$ & $\begin{array}{l}\text { Medium } \\
\text { sand \% }\end{array}$ & Fine Sand \% & Silt \% & Clay \% \\
\hline TP1 & 9.97 & 1.42 & 13.11 & 7.77 & 47.69 & 20.04 \\
\hline TP2 & 15.80 & 7.20 & 10.33 & 12.88 & 17.78 & 35.50 \\
\hline TP3 & 14.88 & 10.22 & 22.52 & 4.45 & 33.42 & 14.50 \\
\hline TP4 & 16.19 & 15.02 & 20.13 & 8.12 & 16.54 & 24.00 \\
\hline TP5 & 12.78 & 10.91 & 25.72 & 11.77 & 29.81 & 9.00 \\
\hline TP6 & 11.88 & 8.31 & 20.72 & 12.06 & 15.82 & 31.20 \\
\hline TP7 & 12.18 & 15.62 & 21.52 & 17.12 & 22.46 & 14.10 \\
\hline TP8 & 13.83 & 8.73 & 10.37 & 6.89 & 40.10 & 20.08 \\
\hline TP9 & 9.18 & 16.03 & 18.12 & 10.12 & 27.50 & 19.04 \\
\hline TP10 & 12.19 & 9.63 & 16.54 & 16.83 & 27.68 & 17.12 \\
\hline \hline
\end{tabular}

Gradation Curve

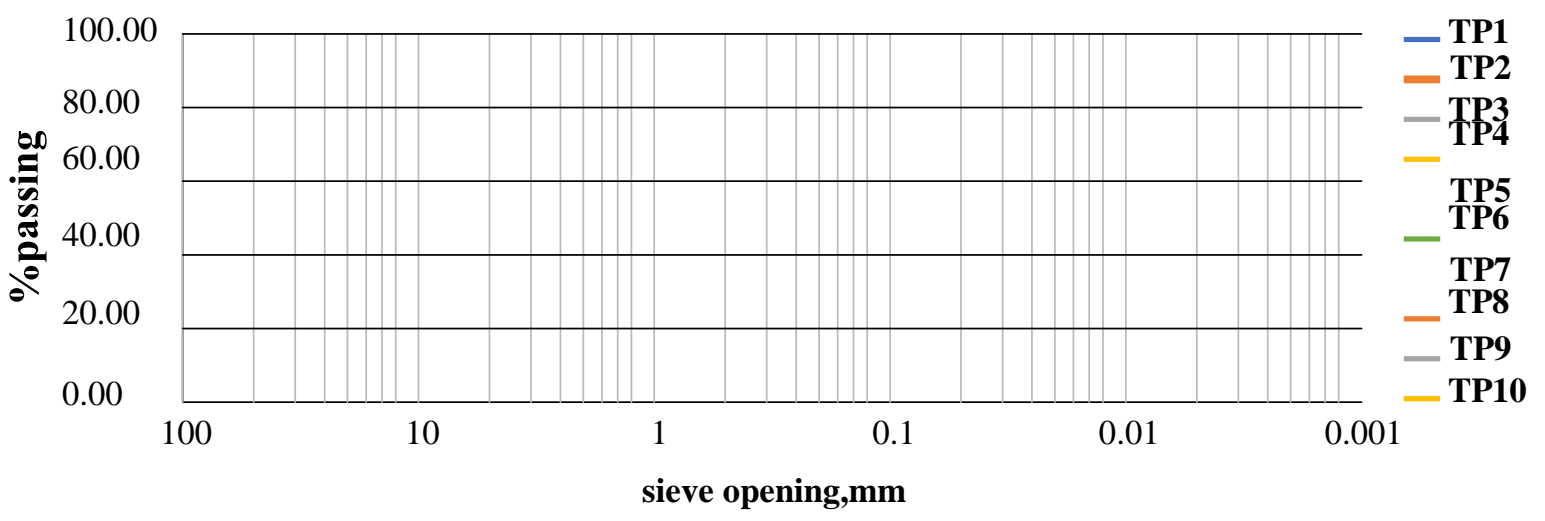

Figure 1. Gradation Curves of the Study Area.

Table 6. Atterberg Limit, Compaction, CBR Swell, CBR Test Results and Soil classification.

\begin{tabular}{|l|l|l|l|l|l|l|l|l|l|}
\hline $\begin{array}{l}\text { Sample } \\
\text { No. }\end{array}$ & PL \% & LL\% & PI \% & $\begin{array}{l}\text { OMC } \\
\%\end{array}$ & $\begin{array}{l}\text { MDD } \\
\mathrm{g} / \mathrm{cm}^{3}\end{array}$ & $\begin{array}{l}\text { CBR } \\
\%\end{array}$ & $\begin{array}{l}\text { CBR } \\
\text { Swell } \\
\%\end{array}$ & $\begin{array}{l}\text { AASHTO } \\
\text { Soil } \\
\text { Classification }\end{array}$ & $\begin{array}{l}\text { Unified } \\
\text { Soil } \\
\text { Classification }\end{array}$ \\
\hline TP1 & 32.91 & 45.68 & 12.77 & 21.37 & 1.83 & 6.74 & 1.81 & $\begin{array}{l}\text { A-7-5(9) } \\
\text { Medium Sults of } \\
\text { compressibilit }\end{array}$ \\
\hline
\end{tabular}

\begin{tabular}{|l|l|l|l|l|l|l|l|l|l|}
\hline TP2 & 30.04 & 44.04 & 14.00 & 10.14 & 1.98 & 7.21 & 1.64 & A-7-5(8) & $\begin{array}{c}\text { Inorganic Silts of } \\
\text { Medium } \\
\text { compressibilit y }\end{array}$ \\
\hline TP3 & 24.30 & 37.67 & 13.37 & 14.61 & 1.88 & 8.03 & 1.61 & A-6(5) & $\begin{array}{l}\text { Inorganic Silts of Medium } \\
\text { compressibility }\end{array}$ \\
\hline TP4 & 26.23 & 37.20 & 10.97 & 10.20 & 1.94 & 8.71 & 1.56 & A-6(7) & $\begin{array}{c}\text { Inorganic Silts of } \\
\text { Medium } \\
\text { compressibilit y }\end{array}$ \\
\hline
\end{tabular}




\begin{tabular}{|l|l|l|l|l|l|l|l|l|l|}
\hline TP5 & 24.71 & 32.92 & 8.21 & 11.90 & 1.91 & 8.76 & 1.42 & A-4(4) & $\begin{array}{l}\text { Inorganic Silts of Medium } \\
\text { compressibility }\end{array}$ \\
\hline TP6 & 28.34 & 42.95 & 14.61 & 16.43 & 1.88 & 6.43 & 1.85 & A-7-6(11) & $\begin{array}{c}\text { Inorganic Silts of } \\
\text { Medium } \\
\text { compressibilit y }\end{array}$ \\
\hline TP7 & 24.20 & 37.47 & 13.27 & 13.85 & 1.79 & 8.23 & 1.58 & A-6(6) & $\begin{array}{c}\text { Inorganic Silts of Medium } \\
\text { compressibility }\end{array}$ \\
\hline TP8 & 33.28 & 45.71 & 12.43 & 16.37 & 1.91 & 7.61 & 1.63 & A-7-5(10) & $\begin{array}{c}\text { Inorganic Silts of } \\
\text { Medium } \\
\text { compressibilit y }\end{array}$ \\
\hline TP9 & 29.81 & 41.81 & 12.00 & 14.19 & 1.84 & 6.31 & 1.92 & A-7-6(11) & $\begin{array}{c}\text { Inorganic Silts of Medium } \\
\text { compressibility }\end{array}$ \\
\hline TP10 & 31.06 & 44.16 & 13.10 & 15.32 & 1.77 & 6.56 & 1.83 & A-7-5(10) & Inorganic Silts of \\
Medium \\
\hline
\end{tabular}




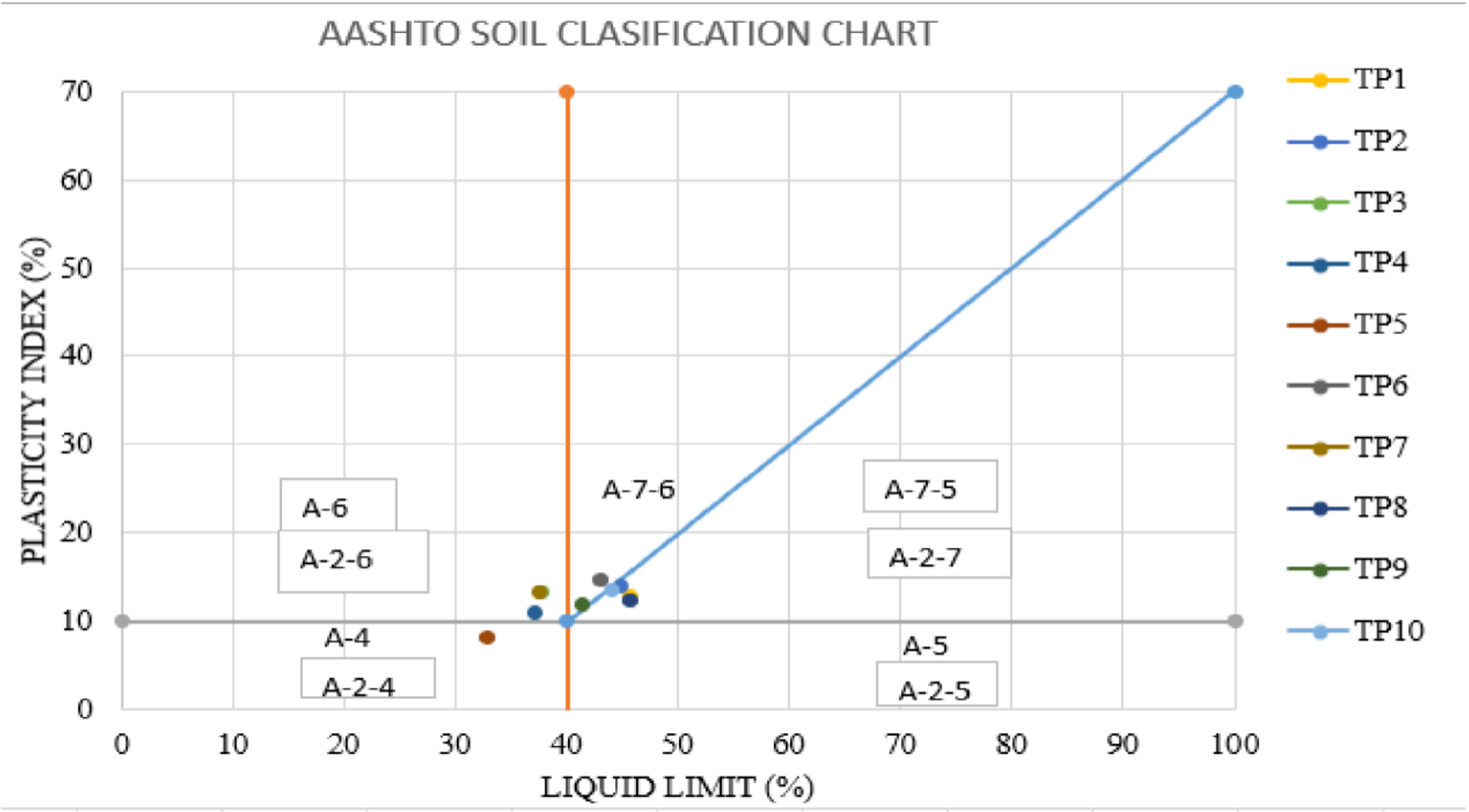

Figure 2. The Study Area Soil Classification Chart According to AASHTO System.

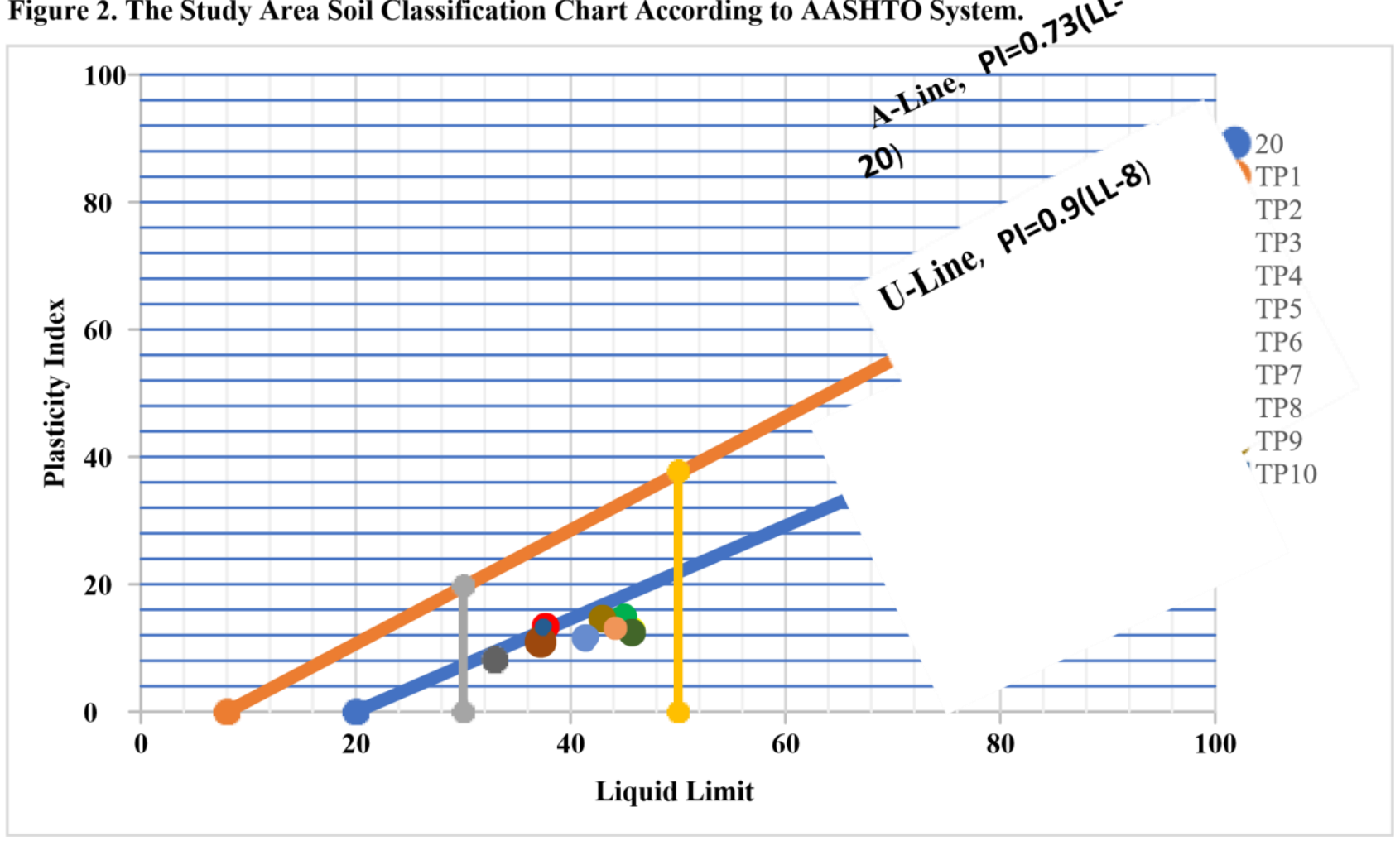

Figure 3. Soil Classification Based on Plasticity Chart for the Study Area. 


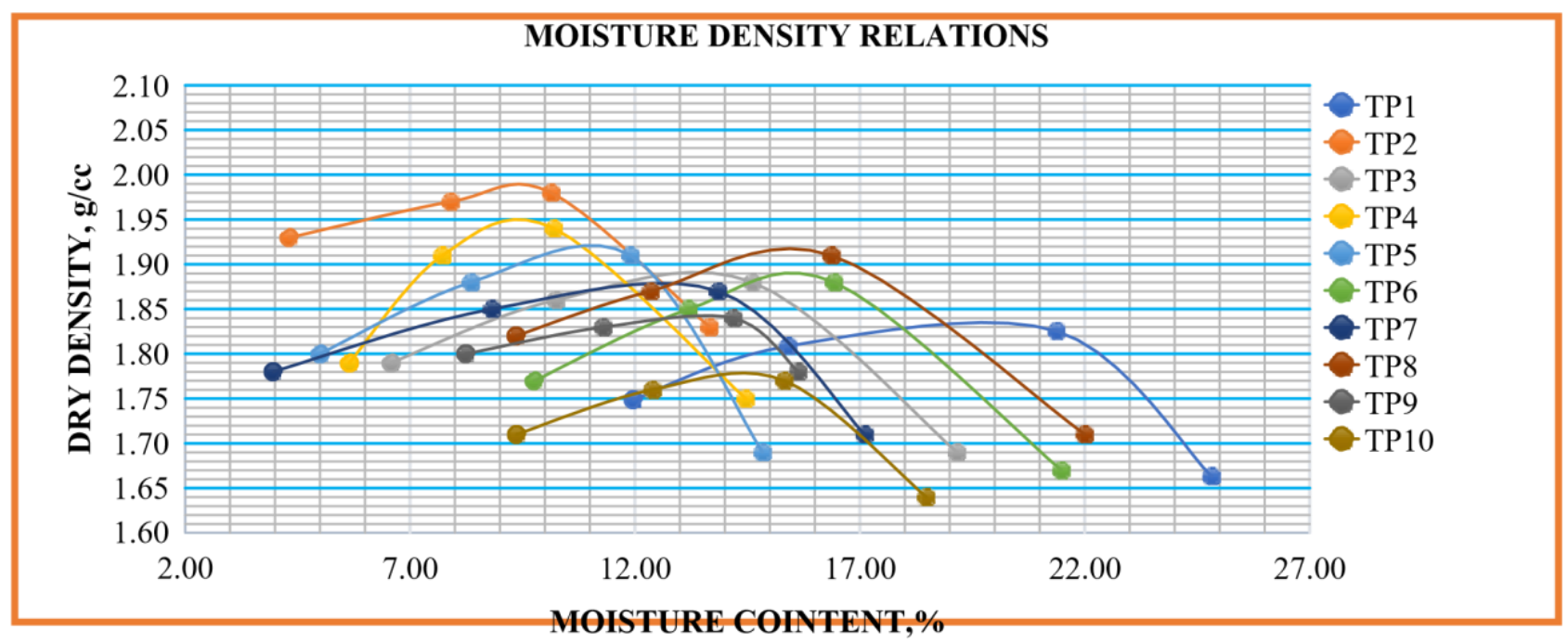

Figure 4. Moisture Density Relations of The Study Area.

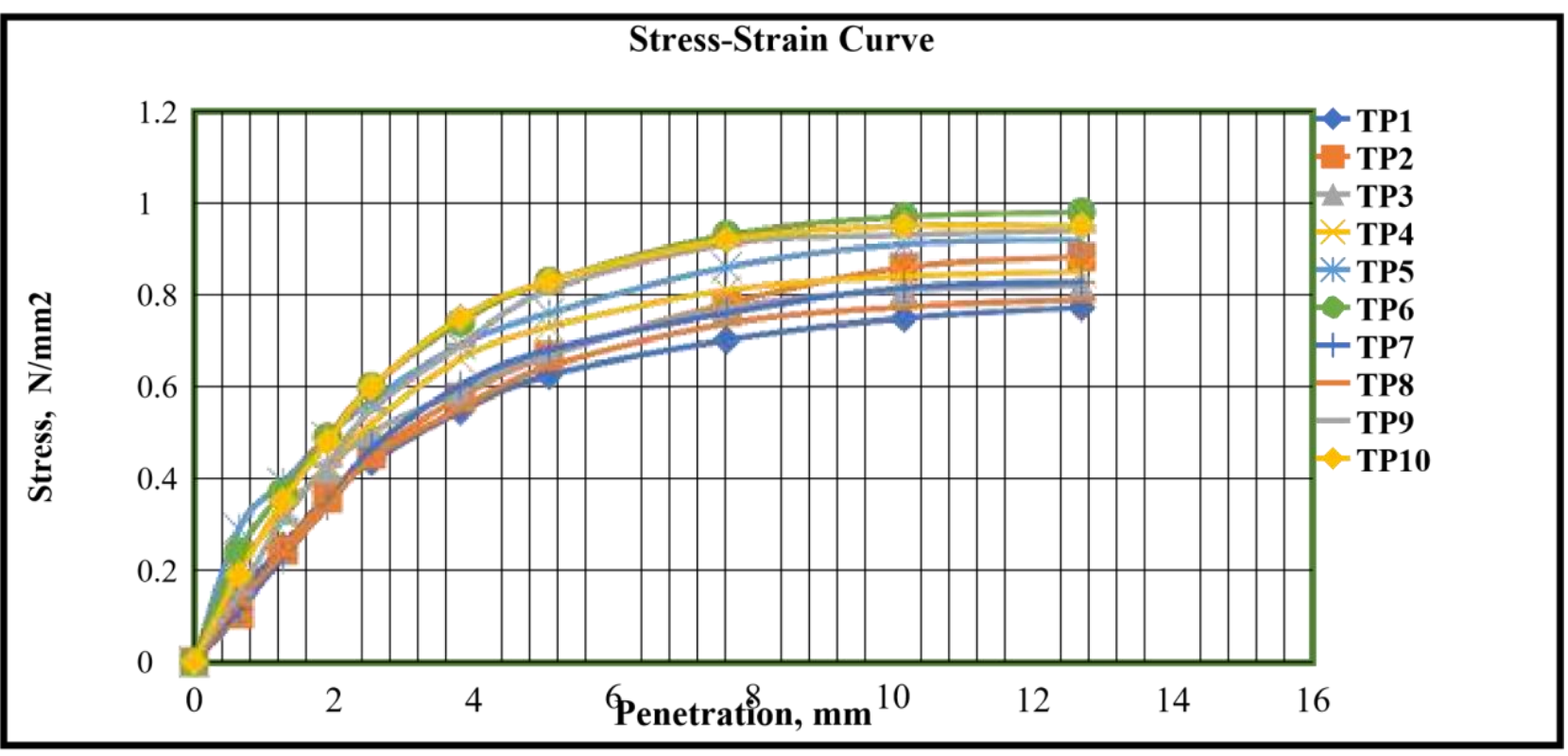

Figure 5. Stress Vs Strain Curves of the Study Area

\section{CONCLUSTIONS}

$>$ It was observed from the experimental results that, all soils samples were fine-grained soils.

$>$ The soils were classified as A-4, A-6, A-7-5 and A-7-6 [1].

$>$ Based on plasticity chart for all soil samples results below the U line, and the soils samples because results below this line indicate correct in testing [2].

$>$ All soil samples were inorganic silts of medium compressibility.[16]

$>$ It was observed from the test results, the LL and PI values indicates that the soil samples were good to use as a foundation soil for pavement construction because of having low swelling potential [10].

$>$ Classification of soil based on the value of GI, for all soil samples were good to use as a subgrade soil [4].

$>$ The CBR swelling potential values were below $2 \%$, therefore they were good to use as a subgrade soil for pavement construction [6].

$>$ The CBR values for the soil samples were above $5 \%$ so they were good to use as a subgrade soil for pavement construction [11].

$>$ From all soil samples the subgrade strength class based on CBR value TP1, TP6, TP9, TP10 were S3; and the remaining were S4 [7].

Generally; the subgrade material for the soil samples were good to use as a subgrade soil for pavement construction based on [4]. 


\section{REFERENCES}

[1] AASHTO. (2013). Standard Specification for Transportation Materials and Methods of Testing and Sampling. .Washington DC.

[2] Dr.A. Paulmakesh, Yimam Mohammed Yimer April 2021, "Implementation of Project Management for Strategy Realisation" Journal of University shanghai for Science and Technology , Volume 23, Issue 10,Pg.No 887-892

[3] Arora, R. K., 2004. Soil Mechanics and Foundation Engineering. 6th ed. Nia sarak, India: Standard Publisher Distributers.

[4] Budhu, M. (2000). Soil Mechanics and Foundations, 3rd edtion. United States of America.

[5] Yimam Mohammed, A. Paulmakesh, Bereket Admasu amd Saliha Shukri, Oct 2021, "Relationship between California Bearing Ratio and Other Geotechnical Properties of Sub grade Soils", ICEPAE 2021,Journal of Physics Conference Series, Vol 2040(1):012024, doi:10.1088/1742-596/2040/1/012029, pg.no 1-13.

[6] ERA. (2002). Pavement Design Manual Volume I Flexible Pavement and Gravel Roads. [7] ERA. (2002). Site Investigation Manuals.

[8] Yimam Mohammed Yimer, A. Paul Makesh and SalihaShukri Muhammed, Oct 2021, "Prediction of undrained shear strength and correlation in between soil parameters", ICEPAE 2021, Journal of Physics Conference Series, Vol 2040(1):012029, doi:10.1088/1742-6596/2040/1/012024 pg.no 1-8.

[9] ERA. (2002). Standard Technical Specification of Subgrade, Subbase, Base and Gravel Wearing Courses. [10 ] Dr.A. Paulmakesh, Dec 2021, "Analysis of uncertainty in a construction project" YMER journal, Vol 20,Issue 12, pg.no 324-332.

[11] ERA. (2013). Pavement Design Manual Volume I Flexible Pavements.

[12] ERA. (2013) Site Investigation Manual.

[13] ERA. (2016) Design of Low Volume Roads.

[14] Murthy, V. N. S., 2006. Geotechnical Engineering: Principle and Practice of Soil Mechanics and Foundation Engineering. 1st ed. New York: Marcel Dekker Inc.

[15] Dr.A. Paulmakesh, Gizachew Markos Makebo April 2021, "Management of contracts for Durable structures" Innovations, Number 64,Pg 1044-1054

[16] Nibret, C. (2011). Geotechnical Characterization of Subgrade Materials for Pavement Construction, A Case Study Aposto-Wondo-Negele Road Upgrading Project. 